\title{
Social Networking Trend in Improving Educational Leadership Competency in Higher Learning: Systematic Data Analysis
}

\author{
Antoni Ludfi Arifin'1 \\ DOI: $10.35445 /$ alishlah.v13i3.478
}

\begin{tabular}{|c|c|}
\hline Article Info & Abstract \\
\hline $\begin{array}{l}\text { Social Networking; } \\
\text { EducationalLeadership; } \\
\text { Learning outcomes; } \\
\text { Data analysis }\end{array}$ & $\begin{array}{l}\text { This study examined social network trends in improving educational leadership } \\
\text { quality and higher learning outcomes through systematic data analysis. Forward } \\
\text { or backwards, the quality of human resources and scholarly output in the } \\
\text { academic environment is closely related to social networking, which is } \\
\text { increasingly becoming a phenomenon today. The researcher has carried out a } \\
\text { series of data collection through electronic searches in several international } \\
\text { publications in various scientific communication contexts to understand this. } \\
\text { Furthermore, the analysis process includes understanding the study questions, } \\
\text { coding, analysis, and in-depth interpretation to obtain valid and reliable study } \\
\text { findings that answer this study's questions. Our e-search, especially on the } \\
\text { Google Scholar data source, ERIC publications, and other online data sources } \\
\text { from the } 2010 \text { to } 2021 \text { publications, was prioritized. Based on the discussion of } \\
\text { results and observations of current social networking trends, it can be concluded } \\
\text { that social networking brings benefits such as building social relationships, } \\
\text { communication, keeping up with renewal, more personal relationships, more } \\
\text { genuine connections, advertising, and other networking among educational } \\
\text { leaders worldwide. }\end{array}$ \\
\hline
\end{tabular}

Kata kunci:

Jaringan Sosial;

Kepemimpinan

Pendidikan;

Hasil Belajar;

Analisis Data

\begin{abstract}
Abstrak
Studi ini meneliti tren jejaring sosial dalam meningkatkan kualitas kepemimpinan pendidikan dan hasil belajar yang lebih tinggi melalui analisis data yang sistematis. Maju atau mundur, kualitas sumber daya manusia dan keluaran keilmuan lingkungan akademik sangat eratnya dengan jaringan sosial yang semakin menjadi fenomena saat ini. Untuk memahami hal tersebut, kami telah melakukan uji coba data melalui pencarian elektronik di beberapa publikasi internasional dalam berbagai konteks komunikasi ilmiah. Selanjutnya proses analisis pemahaman pemahaman permasalahan studi, sistem koding, analisis, dan interpretasi mendalam untuk mendapatkan temuan studi yang valid dan reliabel. Penelusuran elektronik, terutama pada sumber data Google Cendekia, publikasi ERIC, dan sumber data online lainny a dari publikasi 2010 hingga 2021, diprioritaskan. Berdasarkan pembahasan hasil dan pengamatan tren jejaring sosial saat ini, dapat menunjukkan bahwa situs jejaring sosial membawa manfaat seperti membangun hubungan sosial, komunikasi, menjaga pembaruan, hubungan yang lebih pribadi, koneksi yang lebih asli, periklanan, dan jejaring lainnya antara pemimpin pendidikan di seluruh dunia .
\end{abstract}

${ }^{1}$ In stitut Ilm u Sosial dan Ma najemen STIAMI

Em ail: $\underline{\text { ludfi@stiami.ac.id }}$ 


\section{INTRODUCTION}

Social networks are considered more important than professionals in improving educational leadership in higher education practice. (Tess, 2013; Aslan, 2019). The reason is, this social networking trend can present specific practical ways to support the potential of educational leadership, both those who work in academia and industry. Kabilan et al. (2010) noted that networking platforms such as Facebook as an online application to improve English communication widely used in higher education institutions are developing rapidly. Through social networks, they can support each other. (Duffett, 2015). Another reason may be that this particular social network, academic and professional community can strengthen their relationships with other people who share the same interests, make new friends, and make new networking sites showcase relevant ideas. In contrast to other forms of internet connectivity, people are increasingly using mobile devices, believing that the network can significantly impact future education, including policymaking in the hands of most leaders in universities as a practical interaction digital communication. (Ahlquist, 2014).

Regarding social networking sites, this platform provides a platform for communities of various backgrounds and expertise outside the station to share experiences through online meetings. That's how social networking is good for the community in an educational setting. He \& Harris (2020) say that social networks appear to have more benefits, especially in pandemic times where more public gatherings and face-to-face interactions have been restricted by the authorities to control and manage pandemic restrictions (Gostin \& Wiley, 2020; Aslan et al., 2020). The community will have opportunities so that more academic organizations and other educational professionals can meet and connect during online sessions. Brady et al. (2010) note that the use of alternative social networking sites in higher education settings is the reason why online social forums help increase the quality of human resources in education and other disciplines as well as a means of limited educational interaction such as face-to-face forums, which are very practical and relevant to be applied in the current COVID-19 situation.

Social networks' effectiveness as a means of communication and their superiority in the interaction was assisted as the technological means. The social networking facility is a social networking platform for online meetings or meetings because it is made for anyone who wants to join in and share without hesitation, like students and teachers, who sometimes it is impossible to get the same information and updates instantly. Not only that, changes in the latest news in exchanging ideas are carried out by individuals and professionals when they meet in person on social networks (Baruah, 2012; Siddiqui \& Singh, 2016; Pindayi, 2017; Amalia \& Suprayogi, 2019). According to Ranieri et al. (2012), how teachers engage in social networks will be constructive because professional networks will have implications for their future learning and building professional nets. According to a professional site, and is still a social network with a professional network of several social networks.

Another network function is where a professional community can meet and develop things like learning English, this side job, and excellent online opportunities. Meanwhile, Pimmer et al. (2012) recognized Facebook as a learning and teaching site by studying the appropriateness of small social networking spaces in many developing countries that use less online learning. Many professionals are now starting to make friends by creating websites and building professional careers and networks. Several social networks experienced people can use for life, such as the best real-time publishers and many more to take advantage of besides their drawbacks. Another website for social networks that we call connected data aids. An excellent social network with people worldwide can exchange information between communities where they can learn about good use of data and suggest ideas and discuss what professionals will discuss in front of people. However, this is very good for building on each other's progress-discipline and expertise (Chang et al., 2012; Tuten, 2008). 
Good social media networks in education and leadership practices improve educational performance, much needed by the community. This friendship website allows more people to join saints and social situations, called meetings, is also an excellent network for professionals with many professionals (Fraser \& Dutta, 2010). This is an opportunity to build and enhance a network of other professionals. Also, it is an excellent opportunity for people around the world to share a standard view of education and other advances where they are and with anyone. Likewise, other people can also find partners with this website for social. It is the perfect leadership coaching site where they can have a great website that is very good to maintain and develop a career in leadership qualities in a relaxed and social manner (Mergel \& Greeves, 2012). Another application anyone can join is TweenTribune (Mathew \& Guru, 2017; Di Pietro et al., 2012), which students can learn via social media to keep up with the latest developments and information worldwide. Other social media, such as learning buddy seekers, can join, such as the Blackboard application. Krouska et al. (2019) said through a social network-based education system using a new ISO-based network. This friendship learning application is a course management system or a place to work as a teacher in learning so that this social media is prepared for educational purposes. For example, other networks can also be done, such as EDU2.0, which is made for teachers looking for opportunities to develop themselves and integrate with the system. Management systems such as media Blackboard and starting EDU22.0 offer more convenient features to build their respective abilities. Individuals to become better professionals (Chunyan et al., 2014).

Regarding the social networking forum community from various expert backgrounds and facts and expertise outside the station and sharing experiences and touches online, social networking is suitable for educational leaders ( $\mathrm{Li}$ et al., 2012). Many say that social networks appear to have more benefits, especially during a pandemic where the authorities restrict more public services to control and manage pandemic restrictions. So that through this social network, there will be opportunities so that more educational professional academic communities can meet and connect during online sessions (Mackey \& Evans, 2011). Online social forums are perfect for improving human resources in education and other disciplines and being a valuable tool between business people and the limited action and face-to-face interaction. This kind of forum is efficient and relevant to be applied. Akram \& Kumar (2017) said that social networking platforms benefit from online meetings because this profile is for anyone to join. On the side, every one is professional to students can get instant information and updates and the latest changes in the exchange field. Ideas carried out by each individual and professional face to face could never happen in real life.

According to Jordan \& Weller (2018), there are similarities and relationships between academic performance and social networking applications. The benefits, solutions, and tension in both personal and professional interactions during online social networking sessions. They added that this professional social networking site lived a social networking site with several professional social networks. Other networking jobs where the world of the professional community can meet and start there for everything they want, such as a name in learning, this side job, posting jobs, and online opportunities are plentiful (DuFour \& DuFour, 2013). Some may build friendships like centres, work on websites outside of life and careers, and network. There are many social networks for professionals who can live it like the best use of real-time for the public, for example, many other things related to self-development.

The functions and advantages of social media in the world of education are well known. As a consequence of social networks and education, a new image has emerged. For example, through friendship on social networking, many people can interact socially and genuinely. For example, students, instructors, and parents benefit from using social networking in education. It allows them to access more relevant material and connect with study groups and other education systems that make learning more accessible. Social networking technology can help students and institutions 
improve their learning techniques in several ways. Thus, the parties will be able to improve leadership skills in the fields they play. A lecturer will have the opportunity to understand his students and vice versa; students will have the opportunity to learn their leadership potential (Daly et al., 2019).

Because the benefits of social networking for educators and students have been stated above, there is no reason for students and lecturers not to use social networks. Through this network, efforts to maintain contact with each other's friends can be maintained, which in the end, they communicate with each other and even collaborate on the interests they like. To make it easier for them to communicate, they keep each other up to date with the latest headlines in real-time (Poell \& Van Dijck, 2015). So to engage on a more intimate level, networking media will be beneficial. Make friends with their "likes" and interests. For the sole purpose of free publicity. To express themselves artistically so that the leadership potential of their respective fields can be continuously improved. On this basis, this study is conducted to gain a deeper understanding (Singh et al., 2016).

\section{METHODS}

This study aimed to analyze how social networking trends in improving educational leadership competencies in higher education. We believe that communication and interaction on social networks will increase the opportunities for leadership competence for academics in higher education through systematic data analysis. Through a review of more than 60 publications, we have understood the quality of human resources and scientific production in the academic environment, closely related to the social networks, which is increasingly becoming a current phenomenon. We have collected data through electronic searches in several international publications in various scientific communication contexts to examine this. We get data by typing keywords in databases such as Google Books, Sagepub, Taylor \& France, and the publication Academy. The keywords we mean are, for example, "educational leadership," "social networking," "improving competency." Then the analy sis process includes understanding the research questions, coding, critical analysis, and in-depth interpretation to obtain valid and reliable research findings that answer this research question. Our electronic search and secondary data sources from 2010 to 2021 were carried out. We follow all research processes and report design. We followed the direction of descriptive qualitative experts (Gholami-Kordkheili et al., 2013).

\section{FINDINGS AND DISCUSSION}

\section{Social Networking in Leadership Change}

As emphasized at the beginning of this paper, this study aims to determine social networking trends according to media experts and learning innovation. Boholano, (2017) to increase educational leadership competence in higher education. So through an in-depth analysis of journal data for scientific publications, we will understand the evidence of the study results and how to apply them to future developments.

The first evidence is Leonardi (2014), where his research states that social media is a means of sharing information and innovation, especially human resources in universities. Now under half of the staff use web-based media for guidance. The younger workforce reported $55.7 \%$ more use of social media than more experienced staff. Staff in the arts and humanities demonstrated higher utilization of web-based media than all orders. The safety and honesty of online surrogate entries emerged due to personnel limitations in using web-based media. There is a strong relationship between personnel use for proficient and instructive purposes, which are more frequently used for personal reasons than instructional purposes. Most use social media more often for individual purposes because authentic learning is personalized rather than classroom learning with conventional formality and nuances. Al Hashimi et al. (2019) also see this social media approach as 
a pedagogy-based tool that effectively enriches creativity in art, design, and students' digital media globally, part of the new technology acceleration of modern-day learning.

Foreign language skills are also potentially critical in enhancing the quality and instructional leadership of higher education leaders. Xodabande (2017) study at the adequacy of online media network cables in demonstrating English articulation to EFL departments' academic quality in Iran. This study analyzes a telegraphic web-based media network's adequacy in demonstrating English fluency to EFL students and teachers among native English-speaking academics. Analysts found no irregularities when academic comas interacted on social media networks. A critical increase in the expression of members in the trial group from the final test to the deferred test was conducted a month later. According to scientists, the side effect of social media networks' study found that leveraging web-based media networks to direct foreign language highlights can be powerful and promising. Exams are distributed in scientific diaries on the pronunciation of English as a foreign language. This research proves how social networking proves that quality leadership among academics can be helped. (Ahmmed \& Salim, 2019) in their study of website-based social media's impact on youth leadership. Findings understand web-based media capabilities in higher education through study, development, and instrument approval. This study combines 28 items and four measures-specific ease of use, content translation, content age, and expected reflection collected from a sample of 622 students. The instrument can assess and improve web-based media's fitness level in further education, say the creators. The investigation found that the devices did not indicate flaws in the legitimacy or unshakable quality. In other words, this evidence clearly shows the superiority of social networks in increasing the competence of their users. (Dewey et al., 2012).

Holder-Ellis (2015) attests to web-based media innovation tools in educational guidance and leadership in high and secondary schools. Educators at Western Caribbean universities occasionally use web-based media tools for teaching, learning, exams, and seminars. This contextual investigation tends to involve actual employees of online media innovation tools in continuing education guides. The proposal for this business study can help implement and coordinate the web-based media tools in the direction. This effort adds to social change through employees' more down-to-earth understanding of the supportive elements and barriers that prevent their heavy use of principles, say the creators. The findings from this investigation will spread results to partners to initiate cooperative interactions centred on using social media tools in training and learning. (Emeagwali, 2011).

Lim et al. (2016) examined the means, commitment, and survival of professional scientists through a deliberate survey of assessment systems used in the advancement of well-being through the purpose of long-distance informal communication and networking. The purpose of everyday communication (SNS) is becoming an increasingly prominent place for welfare advancement. Welfare improvement mediation is often not formally assessed. This exam is expected to illustrate the assessment exercises used in the SNS of welfare progress. Barriers to grading include low interest rates, high fixed losses, unclear representation, and no exam meetings. Almost no examination has the option of evaluating the use of mediation. The setting and while surveying the feasibility of intercession with thorough research, the investigation found success in increasing intellectual professionalism and leadership in higher education (Roeser et al., 2012).

\section{Improving Leadership Skills}

Siddiqui \& Singh (2016) searched to understand how social media increasing leadership resources' social benefits bring more benefits. They believe that social media can give different colors to cognitive and affective. Their findings are part of technology and international collaboration for professionals in evidentiary studies with social media networking applications. Social media platforms for professionals are not only for discussing social issues but also for exchanging opinions and scientific findings related to their careers and professions. Previously, 
many people thought that the social media aspect was for people to have fun. However, now, many people already know what social media is for business and career advancement. This computerbased networking allows professionals to share or exchange data, insights, images, video content, and even more direct interaction with each other through various digital-based platforms. They conclude that social media has become a beautiful network for professional development in all social aspects with more positive but less negative impacts. With discussion of specific fields such as business activities, education, change-loving societies, and millennial youth. Their paper has explained how this proven media network influences professional users on a massive and spontaneous basis.

Another way of improving leadership in higher education is Moorley \& Chinn (2016) by making nursing administration in online media. Web-based media may be an instrument to maintain authority today. Officers with appropriate positions of power within the association, for example, the National Health Service, are starting to use online media. Web-based media and formal nursing initiatives need not conflict with each other, but they can both work in a friendly manner because legal and online authorities are adaptable. Using information and web-based media listening tools for nursing pioneers can seek understanding and knowledge into a wide variety of problems. Web-based media also places parenting pioneers in honest and open situations as a good example (Ahlquist, 2014).

This is evident from Erçetin \& Bisaso, (2016) study, which involved women's initiatives in complex web-based media and informal long-distance communication frameworks. Authority is possibly the central angle in human change events and perhaps the most vital foundation of amiability. The hardships experienced and how pioneering women can create due to the confusing online media and interpersonal organizations' world are critical issues for teachers, pioneers, and analysts alike. This paper positions itself as a deliberate attempt and activity to investigate the tests presented by web-based media to initiatives, especially women's authorities, from a very plausible angle (Ahlquist, 2014).

Cullen-Lester et al. (2017) examined how to join interpersonal organizations into events turnover initiatives and applied models and exploration and practice assessments. Multilevel and social perspectives on administration are increasingly becoming the focal point of the advancement of authority. The study said three ways to deal with the progress of the network upgrade administration could raise the limits of the initiative. The test outperformed research enhancement initiatives as far as consolidating networks, they said. They intend to enhance future exploration by explaining each organisation's goals, objectives, and basic system, improving the improvement administration approach in our model that makes sense (Daly et al., 2019).

The latest findings from Sutanto et al. (2011) were the new authority in virtual cooperation arrangements with an interpersonal, organizational investigative approach. Social programming frameworks, such as virtual universes and chat rooms, present immense freedom to organizations today. This exam attempts to encourage our efficient understanding of social programming frameworks for information sharing practices. The best developing pioneers expect intervention rather than coordinating or observing passages during virtual co-efforts, which is predictable across the two social programming frameworks explored. Investigations assume that informal community development is an excellent indicator of someone being seen as a frontrunner by other virtual peers (Kratochwill et al., 2013).

This section will discuss the results of a study of efforts to understand networking media's effectiveness in the potential for educational leadership in higher education. Of the 50 published papers that we studied confirming the effectiveness of social media networks, it has been proven to increase the professionalism of leaders in the higher education environment. Because of the impact of networking on the formation of powerful and effective leadership potential. When leaders join the social media environment, they can make it a networking medium to communicate management, innovation, and entrepreneurial skills, especially in higher education. This web- 
based social platform has had a significant impact on academics, the business world, and other non-profits. Findings of this kind are proven by many other studies (Poore, 2015). In working papers on social media use in the teaching and education process. Another finding that demonstrates not only in the education circle will be right on the environment. Bhanot (2012) companies reach their customers and suppliers.

Each study certainly brings results and implications in the world of its respective fields. Likewise, our research has sought new insights into social media's effectiveness in increasing leadership resources among university academics. In terms of efforts to increase leadership capacity in higher education and line with trends in the world of websites in all sectors, there is no mistaking it for decision-makers to switch to alternative solutions that involve networking in increasing academic resources. What's more, the world of social media is now, in fact, no longer a tool for the world outside of professionals. All professions are increasingly turning to the world of social media because of the benefits and effectiveness of social networking. For example, Moorhead et al. (2013) say a new dimension of the world of health. Through the review, they proved the usefulness, benefits, and limitations of social networking networks.

So if the context of other professions is sure of the data from the study results, then it is not wrong for academics to understand the effectiveness of networking in increasing the human resource skills of the academic environment. As researchers, we are dedicated to getting verified information. However, we also understand that we are not involved in original scientific research, we also examine what the experts outside of educational studies say so that we can refer to the evidence of evidence in the academic and social media community to help people evaluate and retrieve the data we get through the study. Bond et al. (2020) review mapping studies in academic engagement and instruction technology on sustainability education so that more people can enjoy the findings from the latest educational technology studies among universities. Judging from the trend of increasingly down-to-earth social networks, it seems unlikely that the academic world will stick to the conventional way, namely increasing leadership resources through formal educational channels. The author believes that social networks will increasingly become a world university that will explode in popularity in the coming years. As online and smartphone technology-based social media users proliferates in emerging markets, it will drive growth. (Marjanovic et al., 2013). People will be in all sectors through mobile devices and social media, not except in increasing the capacity of academic resources connected to social networks. Digital advertising and expanded internet connectivity across multiple devices have influenced the media patterns of social networks, like mobile videos that are on the rise. Mader et al. (2013) back up this claim by monitoring the network's progress between higher education institutions and global actors.

\section{CONCLUSION}

Finally, the study of social network trends in improving educational leadership competence in higher education settings through review and analysis of published data has produced results similar to what we have planned. Namely, of the 60 papers that we have systematically reviewed, it has confirmed a deep understanding of the involvement of professional scientists in social media networks to increase the capacity of knowledge in the academic line. The reason for this connection is evidenced by the number of studies that say that more and more professionals are joining the world of social media. On the grounds of this website-based media's effectiveness and practicality, which allows the use of various layers of knowledge to be together and share their expertise and interest. It also contributed that E-learning and social networking are closely related. It is an arena of talent and infinite resources for higher education. 


\section{REFERENCES}

Ahlquist, J. (2014). Trending now: Digital leadership education using social media and the social change model. Journal of Leadership Studies, 8(2), 57-60.

Ahmmed, M. M., \& Salim, Z. R. (2019). The impact of internet on the youth leadership.

Akram, W., \& Kumar, R. (2017). A study on positive and negative effects of social media on society. International Journal of Computer Sciences and Engineering, 5(10), 347-354.

Al Hashimi, S., Al Muwali, A., Zaki, Y., \& Mahdi, N. (2019). The effectiveness of social media and multimedia-based pedagogy in enhancing creativity among art, design, and digital media students. International Journal of Emerging Technologies in Learning (IJET), 14(21), 176-190.

Amalia, A., \& Suprayogi, M. S. (2019). Social Media Chatbots for Collaborated Engagement Marketing. $\quad$ CHANNEL: Jurnal Komunikasi, $\quad 7(1), \quad 33-42$. https://doi.org/10.12928/channel.v7i1.13015

Aslan. (2019a). Hidden Curriculum. https://books.google.co.id/books?hl=en\&lr=\&id=6VCNDwAAQBAJ\&oi=fnd\&pg=PA1\&ots =3MT1BpQ2Sr\&sig=r234cqxo_z9ALakJc4VoXgZ_eHQ\&redir_esc =y\#v=onepage\&q\&f=fal se

Aslan. (2019b). Peran Pola Asuh Orangtua di Era Digital. Jurnal Studia Insania, 7(1), $20-34$. http://dx.doi.org/10.18592/jsi.v7i1.2269

Aslan, A., Silvia, S., Nugroho, B. S., Ramli, M., \& Rusiadi, R. (2020). Teacher's Leadership Teaching Strategy Supporting Student Learning During The Covid-19 Disruption. Nidhomul Haq: Jurnal Manajemen Pendidikan Islam, 5(3), 321-333. https://doi.org/10.31538/ndh.v5i3.984

Aslan, Hifza, Syakhrani, A. W., Syafruddin, R., \& Putri, H. (2020). CURRICULUM AS CULTURAL ACCULTURATION. Santhet: (Jurnal Sejarah, Pendidikan, Dan Humaniora), 4(1), 1-9. https://doi.org/10.36526/santhet.v4i1.86o

Baruah, T. D. (2012). Effectiveness of Social Media as a tool of communication and its potential for technology-enabled connections: A micro-level study. International Journal of Scientific and Research Publications, 2(5), 1-10.

Bhanot, S. (2012). Use of social media by companies to reach their customers. SIES Journal of Management, 8(1).

Boholano, H. (2017). Smart Social Networking: 21st Century Teaching and Learning Skills. Research in Pedagogy, 7(1), 21-29.

Bond, T., Yan, Z., \& Heene, M. (2020). Applying the Rasch model: Fundamental measurement in the human sciences. Routledge.

Bower, M. (2017). Design of technology-enhanced learning: Integrating research and practice. Emerald Group Publishing.

Brady, K. P., Holcomb, L. B., \& Smith, B. V. (2010). The use of alternative social networking sites in higher educational settings: A case study of the e-learning benefits of Ning in education. Journal of Interactive Online Learning, 9(2).

Chang, K. T., Chen, W., \& Tan, B. C. (2012). Advertising effectiveness in social networking sites: Social ties, expertise, and product type. IEEE Transactions on Engineering Management, 59(4), 634-643.

Chretien, K. C., \& Kind, T. (2013). Social media and clinical care: Ethical, professional, and social implications. Circulation, 127(13), 1413-1421.

Chunyan, L., Haitao, C., \& Guolin, L. (2014). The effect of Web2. o on learning management system. International Journal of Multimedia and Ubiquitous Engineering, 9(10), 67-78.

Cullen-Lester, K. L., Maupin, C. K., \& Carter, D. R. (2017). Incorporating social networks into leadership development: A conceptual model and evaluation of research and practice. The Leadership Quarterly, 28(1), 130-152.

Culnan, M. J., McHugh, P. J., \& Zubillaga, J. I. (2010). How large US companies can use Twitter and other social media to gain business value. MIS Quarterly Executive, 9(4).

Daly, A. J., Liou, Y.-H., Del Fresno, M., Rehm, M., \& Bjorklund Jr, P. (2019). Educational leadership in the Twitterverse: Social media, social networks and the new social continuum. Teachers College Record,121(14), 1-20. 
Dewey, D. P., Bown, J., \& Eggett, D. (2012). Japanese language proficiency, social networking, and language use during study abroad: Learners' perspectives. Canadian Modern Language Review, 68(2), 111-137.

Di Pietro, L., Di Virgilio, F., \& Pantano, E. (2012). Social network for the choice of tourist destination: Attitude and behavioural intention. Journal of Hospitality and Tourism Technology.

Duffett, R. G. (2015). Facebook advertising's influence on intention-to-purchase and purchase amongst Millennials. Internet Research.

DuFour, R., \& DuFour, R. (2013). Learning by doing: A handbook for professional learning communities atwork TM. Solution Tree Press.

Effendi, M. I., Sugandini, D., \& Istanto, Y. (2020). Social Media Adoption in SMEs Impacted by COVID-19:The TOE Model. The Journal of Asian Finance, Economics, and Business, 7(11), 915-925.

Emeagwali, N. S. (2011). Millennials: Leading the Charge for Change. Techniques: Connecting Education and Careers (J1), 86(5), 22-26.

Erçetin, Ş. Ş., \& Bisaso, S. M. (2016). Women leadership in complex social media and social networking systems. In Women Leaders in Chaotic Environments (pp. 127-142). Springer.

Fraser, M., \& Dutta, S. (2010). Throwing sheep in the boardroom: How online social networking will transform your life, work and world. John Wiley \& Sons.

Gholami-Kordkheili, F., Wild, V., \& Strech, D. (2013). The Impact of Social Media on Medical Professionalism: A Systematic Qualitative Review of Challenges and Opportunities. Journal of Medical Internet Research, 15(8), e2708. https://doi.org/10.2196/jmir.2708

Gikas, J., \& Grant, M. M. (2013). Mobile computing devices in higher education: Student perspectives on learning with cellphones, smartphones \& social media. The Internet and Higher Education, 19, 18-26.

Gostin, L. O., \& Wiley, L. F. (2020). Governmental public health powers during the COVID-19 pandemic: Stay-at-home orders, business closures, and travel restrictions. Jama, 323(21), 2137-2138.

He, H., \& Harris, L. (2020). The impact of Covid-19 pandemic on corporate social responsibility and marketing philosophy. Journal of Business Research, 116, 176-182.

Hermida, A., Fletcher, F., Korell, D., \& Logan, D. (2012). Share, like, recommend: Decoding the social media news consumer. Journalism Studies, 13(5-6), 815-824.

Hobbs, R. (2010). Digital and Media Literacy: A Plan of Action. A White Paper on the Digital and Media Literacy Recommendations of the Knight Commission on the Information Needs of Communities in a Democracy. ERIC.

Holder-Ellis, M. N. (2015). The role of social media technology tools in higher education instruction.

Honig, M. I. (2012). District central office leadership as teaching: How central office administrators support principals' development as instructional leaders. Educational Administration Quarterly, 48(4), 733-774.

Hughes, A. L., \& Palen, L. (2012). The evolving role of the public information officer: An examination of social media in emergency management. Journal of Homeland Security and Emergency Management, $9(1)$.

Jacobs, H. H. (2010). Curriculum 21 : Essential education for a changing world. ASCD.

Jordan, K., \& Weller, M. (2018). Academics and social networking sites: Benefits, problems and tensions in professional engagement with online networking. Journal of Interactive Media in Education, $2018(1)$.

Jussila, J. J., Kärkkäinen, H., \& Aramo-Immonen, H. (2014). Social media utilization in businessto-business relationships of technology industry firms. Computers in Human Behavior, 3O, 606-613.

Kabilan, M. K., Ahmad, N., \& Abidin, M. J. Z. (2010). Facebook: An online environment for learning of English in institutions of higher education? The Internet and Higher Education, $13(4), 179-187$.

Kaplan, A. M., \& Haenlein, M. (2010). Users of the world, unite! The challenges and opportunities of Social Media. Business Horizons, 53(1), 59-68. 
Khan, M. L., Wohn, D. Y., \& Ellison, N. B. (2014). Actual friends matter: An internet skills perspective on teens' informal academic collaboration on Facebook. Computers \& Education, 79, 138-147.

Kratochwill, T. R., Hitchcock, J. H., Horner, R. H., Levin, J. R., Odom, S. L., Rindskopf, D. M., \& Shadish, W. R. (2013). Single-case intervention research design standards. Remedial and SpecialEducation, 34(1), 26-38.

Krouska, A., Troussas, C., \& Virvou, M. (2019). A literature review of Social Networking-based Learning Systems using a novel ISO-based framework. Intelligent Decision Technologies, 13(1), 23-39.

Lee, Y.-C. (2011). Enhancing pedagogical content knowledge in a collaborative school-based professional development program for inquiry-based science teaching. Asia-Pacific Forum On Science Learning \& Teaching, 12(2).

Leonardi, P. M. (2014). Social media, knowledge sharing, and innovation: Toward a theory of communication visibility. Information Systems Research, 25(4), 796-816.

Li, Y.-M., Liao, T.-F., \& Lai, C.-Y. (2012). A social recommender mechanism for improving knowledge sharing in online forums. Information Processing \& Management, 48(5), 978994.

Lieb, R. (2012). Content marketing: Think like a publisher-how to use content to market online and in social media. Que Publishing.

Lim, M. S., Wright, C. J., Carrotte, E. R., \& Pedrana, A. E. (2016). Reach, engagement, and effectiveness: A systematic review of evaluation methodologies used in health promotion via social networking sites. Health Promotion Journal of Australia: Official Journal of Australian Association of Health Promotion Professionals, 27(3), 187-197.

Livesey, P. V. (2017). Goleman-Boyatzis model of emotional intelligence for dealing with problems in project management. Construction Economics and Building, 17(1), 20-45.

Mackey, J., \& Evans, T. (2011). Interconnecting networks of practice for professional learning. International Review of Research in Open and Distributed Learning, 12(3), 1-18.

Mader, M., Mader, C., Zimmermann, F. M., Görsdorf-Lechevin, E., \& Diethart, M. (2013). Monitoring networking between higher education institutions and regional actors. Journal of Cleaner Production, 49,105-113.

Marjanovic, S., Hanlin, R., Diepeveen, S., \& Chataway, J. (2013). Research capacity -building in Africa: Networks, institutions and local ownership. Journal of International Development, 25(7), 936-946.

Marwick, A. E. (2013). Status update: Celebrity, publicity, and branding in the social media age. Yale University Press.

Mathew, A., \& Guru, B. M. C. (2017). Social Networking Sites For Educational Development. Editorial Board, 6(8), 225.

Mergel, I., \& Greeves, B. (2012). Social media in the public sector field guide: Designing and implementing strategies and policies. John Wiley \& Sons.

Mohammadian, M., \& Mohammadreza, M. (2012). Identify the success factors of social media (marketing perspective). International Business and Management, 4(2), 58-66.

Moorhead, S. A., Hazlett, D. E., Harrison, L., Carroll, J. K., Irwin, A., \& Hoving, C. (2013). A new dimension of health care: Systematic review of the uses, benefits, and limitations of social media for health communication. Journal of Medical Internet Research, 15(4), e85.

Moorley, C., \& Chinn, T. (2016). Developing nursing leadership in social media. Journal of Advanced Nursing, 72(3), 514-520.

Morgan, J. (2014). The future of work: Attract new talent, build better leaders, and create a competitive organization. John Wiley \& Sons.

Mukhopadhyay, M. (2020). Total quality management in education. SAGE Publications Pvt. Limited.

Nasri, M., Namaziandost, E., \& Akbari, S. (2019). Impact of pictorial cues on speaking fluency and accuracy among Iranian pre-intermediate EF learners. International Journal of English Language and Literature Studies, 8(3), 99-109.

Pimmer, C., Linxen, S., \& Gröhbiel, U. (2012). Facebook as a learning tool? A case study on the appropriation of social network sites from mobile phones in developing countries. British Journal of Educational Technology, 43(5), 726-738. 
Pindayi, B. (2017). Social media uses and effects: The case of Whatsapp in Africa. In Impacts of the media on African socio-economic development (pp. 34-51). IGI Global.

Poell, T., \& Van Diick, J. (2015). Social media and activist communication. Poell, Thomas \& José vanDijck (2015). Social Media and Activist Communication. In The Routledge Companionto Alternative and Community Media, 527-537.

Poore, M. (2015). Using social media in the classroom: A best practice guide. Sage.

Ranieri, M., Manca, S., \& Fini, A. (2012). Why (and how) do teachers engage in social networks? An exploratory study of professional use of $\mathrm{F}$ acebook and its implications for lifelong learning. British Journal of Educational Technology, 43(5), 754-769.

Rennie, F., \& Morrison, T. (2013). E-learning and social networking handbook: Resources for higher education. Routledge.

Roeser, R. W., Skinner, E., Beers, J., \& Jennings, P. A. (2012). Mindfulness training and teachers' professional development: An emerging area of research and practice. Child Development Perspectives, 6(2), 167-173.

Siddiqui, S., \& Singh, T. (2016). Social media its impact with positive and negative aspects. International Journal of Computer Applications Technoloqu and Research, .5(2), 71-7.5.

Singh, M., Alavi, A., Wong, R., \& Akita, S. (2016). Radiodermatitis: a review of our current understanding. American journal of clinical dermatology, 17(3), 277-292.

Sutanto, J., Tan, C.-H., Battistini, B., \& Phang, C. W. (2011). Emergent leadership in virtual collaboration settings: A social network analysis approach. Long Range Planning, 44(5-6), 421-439.

Tess, P. A. (2013). The role of social media in higher education classes (real and virtual)-A literature review. Computers in Human Behavior, 29(5), A60-A68.

Tsimonis, G., \& Dimitriadis, S. (2014). Brand strategies in social media. Marketing Intelligence \& Planning.

Tuten, T. L. (2008). Advertising 2.o: Social Media Marketing in a Web 2.o World: Social Media Marketing in a Web 2.o World. ABC-CLIO.

Xodabande, I. (2017). The effectiveness of social media network telegram in teaching English language pronunciation to Iranian EFL learners. Cogent Education, 4(1), 1347081.

Zhu, S., Hao Yang, H., Xu, S., \& MacLeod, J. (2020). Understanding social media competence in higher education: Development and validation of an instrument. Journal of Educational Computing Research, 57(8), 1935-1955. 